\title{
Comparative Analysis of Students' Satisfaction with Classroom Facilities in Nigerian Private Universities
}

\author{
OLUWUNMI Adedamola O. (Corresponding Author) \\ Department of Estate Management, \\ Covenant University, Ota, Ogun State \\ E-mail: funke.oluwunmi@covenantuniversity.edu.ng \\ Durodola Daniel. O. \\ Department of Estate Management \\ Covenant University, Ota, Ogun State \\ E-mail: femi.durodola@covenantuniversity.edu.ng \\ AJAYI Ayodele C. \\ Department of Estate Management, \\ Obafemi Awolowo University, Ile Ife, Osun State \\ E-mail: ydlajayi@yahoo.com
}

Received: Oct. 18, 2015 Accepted: Nov. 23, 2015 Published: November 23, 2015

http://dx.doi.org/10.5296/jse.v5i4.8442 URL: http://dx.doi.org/10.5296/jse.v5i4.8442

\begin{abstract}
In order for educational institutions to meet national and international standards, users preferences becomes an essential determinant of user satisfaction with facilities provided in such institutions. This study evaluates students' satisfaction with classroom facilities in three (3) private Universities in Ado-Odo Local Government Council Area, Ota, Ogun State, Nigeria. A total of five hundred and seventy (570) questionnaires were administered to students, and four hundred and thirty-two (432) representing 76\% were returned and analysed. It was found that students were satisfied with electricity supply, ceiling finishes, windows/doors and furniture in
\end{abstract}




\section{Macrothink}

Journal of Studies in Education

ISSN 2162-6952

2015, Vol. 5, No. 4

their classrooms but, they were not satisfied with the provision and availability of air-conditioning and internet facilities in classrooms. However, when the results were analysed to reflect the findings for each University, they showed different levels of satisfaction and dissatisfaction. The study recommended that the Management of each University should work continuously towards ensuring that this essential facility is given priority in financial decisions and provisions. Essentially, this study would assist University policy-makers to allocate resources more effectively and efficiently since allocation of resources is critical to attaining excellence in a competitive academic environment.

Keywords: Students' Satisfaction, Classroom Facilities, Private Universities, Educational Institutions, Nigeria 


\section{Introduction}

Educational facilities are provided to ensure a comfortable learning environment where students are trained, and to optimize productivity in the teaching and learning processes. Studies have shown that a close relationship exists between the physical environment and the academic performance of students. Thus, the quality of the products of a University bears a direct relationship with the quality of the facilities deployed in the process of production (Nwagwu, 1978; Ogunsaju. 1980; Asiabaka, 2008). According to these authors, the quality of education students receive bears direct relevance to the availability or lack of physical facilities and the overall atmosphere in which learning takes place. These facilities include laboratories, classrooms, lecture theatres and libraries, among others. It is expected that the facilities must be able to satisfy the needs of the students, apart from being adequately provided, if the best is to be appropriated from them.

In this era of strong competition amongst Universities, students satisfaction surveys are essential tools to measure performance, and show the students that their opinions matter and their responses will instigate change within the University. In line with the foregoing, several studies have focused on students' satisfaction with residential facilities (Amole, 2009; Adewunmi, Omirin and Famuyiwa, 2011) and academic facilities (Manjunatha and Shivalingaiah, 2004; Seneviratne, 2006; Osondu and Solomon-Uwakwe, 2010; Kannappanavar and Swamy, 2012). However, a majority of the studies on academic facilities in Nigeria and other parts of the world dealt with library facilities. This is obviously due to a paucity of research on academic facilities worldwide. It is on this note that this study is set to investigate students' satisfaction with classrooms facilities in three private Nigerian Universities.

\section{Literature Review}

Students, being the primary consumers and beneficiaries of all the academic facilities in educational institutions should be given utmost consideration in satisfaction surveys amongst other users of facilities (Usman, 2010; Arambewela and Hall, 2007; Khan, Ahmed and Nawaz, 2011; Marimuthu and Ismail, 2012). According to Aga and Safakli (2007) and Usman (2010), satisfaction is a user's response on whether a product or service is providing a pleasurable level of consumption-related fulfilment. It plays a major role in determining the originality and accuracy of a system, especially the educational system. The higher the level of satisfaction, the higher will be the level of students' skill development, course knowledge and mentality (Malik, Danish and Usman, 2010).

Numerous studies have been conducted in different countries on students' satisfaction with academic facilities but most of the studies were on library facilities. The study of Seneviratne (2006) evaluated users' satisfaction with available resources; service quality and also assessed future information needs of the users of Postgraduate Institute of Medicine Branch Library at Peradeniya, Sri Lanka. The survey revealed that most of the respondents were very satisfied with overall library services and staff performance, they were moderately satisfied with the print collection; and least satisfied with space and ventilation, lack of study areas and the noisy environment. Another study by Wang and Shieh (2006) investigated the performance 
and overall users' satisfaction with Chang Jung Christian University (CJCU) library. Taiwan. With a sample of sixty (60) respondents comprising of faculty, students and school fellows, the result indicated that apart from responsiveness, overall service quality has a significantly positive effect on overall user satisfaction. In addition, the five most important service quality features ranked by users that affect their satisfaction are: collections, loaning and returning service, overall atmosphere, electronic database system, and online reservation and renewal. In Malaysia, Kassim (2009) evaluated the library's performance by measuring the users' satisfaction with library services, infrastructure/place/space and collection/information provided by an academic library. Using descriptive and inferential statistics, the results showed that on the average, the respondents were only quite satisfied with the library services, infrastructure/place/space, collection/information of the library as a whole. The respondents were relatively most satisfied with infrastructure/place/space $(\mathrm{M}=3.41)$, followed by collection/information $(\mathrm{M}=3.27)$, and library services to users $(\mathrm{M}=3.18)$ in that order. Kannappanavar and Swamy (2010) conducted a study on users' perception of the library and information services in agricultural University libraries in South India. The study administered questionnaire to three categories of users consisting: post graduate students, research scholars and faculty members in five (5) agricultural university libraries. The analysis showed that users were satisfied with the information needs and services of the library. However, faculty members were more satisfied than other categories of user sampled. A similar study conducted by Rehman, Shafique and Mahmood (2011) on user perception and satisfaction with reference Services in University Libraries of Punjab, showed that respondents were satisfied with the reference collection, staff, facilities and services provided but they were not highly satisfied with any category of reference service. In Pakistan, Abbasi, Malik, Chaudhry and Imdadullah (2011) measured the level of student satisfaction with services offered by Bahauddin Zakariya University (BZU), Pakistan. Ten major constructs i.e. teaching, administrative/management support, transportation, library, computer labs and general labs, accommodation, medical, sports, prayer/religious facilities, and classroom facilities were used. Mean analysis reflected students dissatisfaction with many core services and facilities like teaching, administrative support, library, labs, accommodation, medical, and sports, while satisfaction has been reported only in three augmented areas i.e. transportation, classroom and prayer facilities. Yusoff (2011) identified and evaluated the drivers that influence business students' satisfaction in the Malaysian private educational environment. Results using SPSS and quadrant analysis revealed that students were satisfied and placed more importance on the physical facilities (e.g. decoration, lighting, layout, toilet facilities e.t.c.) of the institution, followed by the teaching and learning drivers.

Similarly in Nigeria, several studies have also been carried out on students' satisfaction with library facilities. The study of Tella, Owolabi and Attama (2009) examined the use of the library by students at the Akanu Ibiam Federal Polytechnic in Nigeria. Using a combined quantitative (questionnaires administered on students) and qualitative (in-depth interview with staff) approach, the study sampled 1,000 students and 15 staff of the Polytechnic. Results revealed that students were satisfied with the library collections and services. However, their satisfaction could be enhanced if the school library had been networked with internet facility. Another study by Adeniran (2011) analysed the relationship between service 
quality and users' satisfaction with academic library services in Redeemer's University, Mowe. The result of the questionnaires administered on seven (7) academic staff and one hundred and seventy nine (179) students showed that users were satisfied with the services of the library. The work of Iwhiwhu and Okorodudu (2012) on users' satisfaction with library information resources, facilities and services in Edo State Central library, Benin-City revealed that users were not satisfied with the information resources but satisfied with three services provided in the library, which were hours of service, labelling services and bindery services with a mean of $2.87,2.32$ and 2.88 respectively. However, they were satisfied with the furniture available.

From the above review, it is obvious that library facilities have been the centre of research both abroad and in Nigeria, however, few studies exist on classrooms facilities. The work of Kleen, Shell and Cox (1999) in the US focused on students' satisfaction with instructional technology used in the business classroom. The study revealed that students in the various disciplines did have different levels of satisfaction with various technologies such as overhead transparencies, computer slide shows, software demonstrations, and student in-class computer activities. The authors found that satisfaction varied little by gender or by respondent age group, although satisfaction varied with intensity of technology use in some ways. In another study in the US, Kleen, Shell, and Zachry (2001) measured students' satisfaction with technology tools used in Accounting Information System (AIS) classrooms. One hundred and fifty one (151) students in six schools participated in the survey. Student in-class computer activities generated the highest satisfaction among students, live software demonstration the least. However, the authors observed that satisfaction varied little by gender or age group. A related study by Kleen and Shell (2001) measured students' satisfaction with instructional technology tools used in classrooms. The researchers, using a variation of the SERVQUAL instrument observed that student satisfaction varied by course discipline, by instructional technology, by anticipated grade, and by frequency of use. Female respondents were less satisfied than male respondents. Satisfaction generally rose with frequency of use. There are significant variations of satisfaction by discipline and technology choice, but little interaction effect.

In China, Fong-Ling (2010) examined the drivers of student satisfaction and dissatisfaction in the three classroom settings common to higher education: face-to-face, Web-based, and blended classrooms. The Critical Incident Technique was used to collect data and to form categories of satisfaction and dissatisfaction factors. The results indicated that student satisfaction/dissatisfaction factors change in different classrooms. In face-to-face classrooms, the instructor's teaching ability and level of enthusiasm are the most critical factors while availability of the online learning system is the most critical factor in both Web-based and blended learning contexts. The mix of different interaction types makes the blended classroom popular with students. The author is of the opinion that regardless of classroom environment, a collaborative learning style is a key factor in achieving students' satisfaction, which leads to better learning performance.

Yang, Becerik-Gerberb and Mino (2013) took a statistical approach to assess ambient, spatial, and technological attributes that can be found in higher education classrooms through an online survey conducted in six classrooms in a university in the US. The paper provided 
insight for future evaluation of higher education learning environments by linking two Likert scales: one rating student satisfaction with classroom attributes and the other rating the impact of these attributes on student performance. The results revealed that student perceptions rely heavily on spatial attributes, specifically visibility and furniture, and ambient attributes, specifically air quality and temperature, which are highly impacted by the design, management and maintenance of classrooms. Results on the impacts of non-classroom factors i.e. gender, seating location, cumulative GPA, college year and expected course grade on student perceptions of learning environments showed that their perceptions of visibility, acoustics and furniture were more sensitive to non-classroom factors, followed by temperature, air quality, artificial lighting, room layout and software.

In India, Rajesh, Akhil, Muhammad, Sachin and Vishnu (2014) focused on the students' perception of current teaching-learning environment. A total of 178 questionnaires were administered on students of one of the engineering colleges in the State of Kerala in India. Findings indicated a weak 'Technology' interface, i.e., use of modern IT \& Communication facility is low, internet facility is inadequate. In the 'General environment' dimension, heat-stress, glare and audibility are a cause for concern while in the 'Work environment' dimension, physical configuration due to furniture arrangement is a cause for concern. The authors suggested improvement in technology by providing stable internet facility and connectivity, improvement in the 'Work environment' through ergonomic design of furniture and its layout, while 'General environment' could be improved through better air circulation or air-conditioning. The paper concluded that traditional classrooms with rows of desks facing the teacher and the board do not fulfill present day educational needs and expectations; therefore adaptation to new contexts and roles in education is advocated.

These studies, though relevant to this present research, did not focus on ancillary facilities such as cooling systems, building design, conveniences and finishing in classrooms. Moreover, the studies were not conducted in Nigeria, particularly not in Nigerian private Universities. To this end, this study considered students' satisfaction with classroom facilities in three private Universities in Ogun State, Nigeria

\section{Research Methods}

This study employed the statistical formula by Asika (2004) to determine suitable sample size for students in the selected private Universities. The formula is as follows:

$$
\mathrm{n}=\mathrm{N} / 1+\mathrm{N}(\mathrm{b})^{2}
$$

Where:

$\mathrm{n}=$ required sample size

$\mathrm{N}=$ Population Size

$\mathrm{b}=$ Maximum acceptable error margin $(10 \%)$ 


\section{Macrothink Institute ${ }^{\text {TM }}$}

Table I shows the sample size for the Universities. In all, 570 questionnaires were distributed to students across all three Universities. Simple random sampling technique was used in sample selection. The views of students were measured in a graded manner, using 5-point Likert scale. The data was analysed using descriptive statistical techniques.

Table 1. Details and Sample Size of Selected Private Universities

\begin{tabular}{clcc}
\hline S/N & Name of Institution & Year Established & Sample Size \\
\hline 1 & University A & 2002 & 199 \\
2 & University B & 2005 & 187 \\
3 & University C & 2005 & 184 \\
\hline
\end{tabular}

\section{Results}

From the sample size, a total of 432 (representing 76\%) of the questionnaires were found useful and analysed. Table 2 reveals that the majority of students sampled were Science and Technology based, female, between 16 and 25 years old, in 300 and 400 levels and sponsored by their parents. Other information in relation to this study are analysed in Tables 3.

Table 2. Comparison of Students' Characteristics Across the three Private Universities

\begin{tabular}{|c|c|c|c|c|c|c|}
\hline $\mathbf{S} / \mathbf{N}$ & $\begin{array}{c}\text { Characteristics } \\
\text { /Statistics }\end{array}$ & $\begin{array}{c}\text { Sub- } \\
\text { headings }\end{array}$ & $\begin{array}{c}\text { CU } \\
\text { F (\%) }\end{array}$ & $\begin{array}{l}\text { Bells } \\
\text { F (\%) }\end{array}$ & $\begin{array}{l}\text { CRA } \\
\text { F (\%) }\end{array}$ & $\begin{array}{c}\text { Mean } \\
\%\end{array}$ \\
\hline \multirow[t]{3}{*}{1} & $\begin{array}{l}\text { College of } \\
\text { Student }\end{array}$ & $\begin{array}{l}\text { Science \& } \\
\text { Technology }\end{array}$ & $81(50)$ & $86(74)$ & $118(77)$ & 67 \\
\hline & & $\begin{array}{l}\text { Social } \\
\text { Science }\end{array}$ & $32(20)$ & $30(26)$ & $36(23)$ & 23 \\
\hline & & Humanities & $49(30)$ & N/A & N/A & 10 \\
\hline \multirow[t]{2}{*}{2} & $\operatorname{Sex}$ & Male & $90(56)$ & $60(52)$ & $59(38)$ & 49 \\
\hline & & Female & $72(44)$ & $56(48)$ & $92(62)$ & 51 \\
\hline \multirow[t]{4}{*}{3} & Age & $<16$ yrs & $0(0)$ & $0(0)$ & $6(4)$ & 1.3 \\
\hline & & $16-20 \mathrm{yrs}$ & $39(24)$ & $53(46)$ & $112(73)$ & 48 \\
\hline & & $21-25 \mathrm{yrs}$ & $123(76)$ & $59(51)$ & $30(19)$ & 49 \\
\hline & & $26-30 \mathrm{yrs}$ & $0(0)$ & $4(3)$ & $6(4)$ & 2 \\
\hline \multirow[t]{3}{*}{4} & Type of & Self & $2(1)$ & $0(0)$ & $0(0)$ & 0.3 \\
\hline & Sponsorship & Parent & $136(84)$ & $96(83)$ & $121(79)$ & 82 \\
\hline & & Guardian & $24(15)$ & $20(17)$ & $33(21)$ & 18 \\
\hline
\end{tabular}

(Note: The Figures in brackets are percentages of responses) 
3.1 Comparative Analysis of Students' Satisfaction with Classroom Facilities in three Private Universities in Ogun State, Nigeria

To achieve the objective of this study, students' satisfaction with their classroom facilities were compared across the three Universities. The result is as shown in Table 3.

Based on a comparison of the ranking of students' satisfaction with classroom facilities across the three (3) private Universities, it is obvious that the predominant satisfying facility amongst students in Universities A and B is electricity supply. This is not far-fetched considering the mode of operation of the proprietor base of the Universities. Both Universities have ancillary outfits that require constant supply of electricity. For instance, University A owns the largest single Christian worship centre in the world, it also has its operations supported by a medical center, transport segment, bakery, service station and microfinance bank amongst others. Its counter part, University B, owns one of the biggest hotels in Ota, Ogun State. The presence of the African Leadership Centre, where great African leaders converge frequently for consultations will invariably lead an illuminated environment around the University Campus. University $\mathrm{C}$ on the other hand, does not seem to command great satisfaction Campus. University $\mathrm{C}$ on the other hand, does not seem to command great satisfaction as far as electricity is concerned from its students. This perhaps might be due a lack of supporting structures that interrelate with the operations of this institution of higher education as the University seems to stand alone. Hence, electricity supply ranked $7^{\text {th }}$ in the ranking of facility satisfaction. However, students in University $\mathrm{C}$ ranked windows/doors as the facility that brings the greatest satisfaction. This is understandable based on the location of this institution of higher learning. The owners of the University, will want to safeguard their investment in the area by the use of sophisticated materials that will stand the test of time, in terms of controlled inlet and outlet. Windows and doors also came up tops in satisfaction by students in University A after visual comfort. This can be attributed to the background of the founder of the Institution. With a background in the study of Architecture, the owner of the University will so much be concerned with aesthetics. This can also explain why finishes and finishing are ranked next in the succeeding order. Finishing and finishes are also tops in the satisfaction ranking in University B considering the calibre of distinguished personalities that make recourse to their structures from time to time. Apart from classroom aesthetics that ranked second in University $\mathrm{C}$, finishing and finishes are not of top satisfaction by the users of the University's facilities. The management of the Institution will perhaps want to make the immediate users of the facility comfortable and neglect scrupulous finishing and finishes. The priority given to the immediate users of such facility could also prompt efficient and effective sewage system and constant water supply in the toilets which the students attest to by ranking both as third in the satisfactory list.

For the least satisfying facility amongst the three Universities, air-conditioner (AC) appears to dominate. In Universities $\mathrm{A}$ and $\mathrm{C}$, air-conditioning is the very least satisfying facility while in University B, air-conditioning (a part of the cooling system together with fan) appeared as the second least satisfying facility. This is might be because of the notion that as Institutions of learning, an overly comfortable environment of learning will distort the very essence of classrooms as students might catch a little nap while lectures are going on. 


\section{Macrothink

Another least satisfying facility is internet facility. The disturbing provision in this facility ranges from shortage of bandwidth, technical hitches with ISPs (Internet Service providers) and the huge financial outlay synonymous with its provision amongst others. University A still performs better in this regard compared to the other Universities as this appears as its fourth least satisfying facility. Internet facility happens to be the least satisfying in University $\mathrm{B}$ while it is the second least satisfying facility in University C. The provision of separate toilet facilities for male and female students also ranked least. This is the second least satisfying facility for both University A and B students. This can be explained in the sense that as citadels of higher learning, that might not be a focus of priority as compared to a Hotel. However, University $\mathrm{C}$ students are more comfortable with the provision of separate toilet facilities for male and female students when compared to Universities A and B. This can be justified on the grounds that the University has a small population and as such the proportional usage of such a facility will tend to be more satisfying than the other two Universities.

Surprisingly, floor finishing appeared as the third least satisfying facility in University A as against aesthetics which the University is known for; less focus on floor finishing could be attributed to the high traffic of engagements and personnel which the University accommodates. Hence, the University is geared towards floor finishes that are rough and built to last and not necessarily appealing to users' satisfaction. In University C, acoustic comfort (sound proofing) appeared as the third least satisfying facility, while in University B provision of fan, air-conditioning and separate toilet facilities for male and female students ranked third least satisfying facilities. 
Table 3. Comparative Analysis of Students' Satisfaction with Classroom Facilities

\begin{tabular}{|c|c|c|c|c|}
\hline \multirow[b]{2}{*}{ Facilities/Service } & \multicolumn{3}{|c|}{ Ranking } & \multirow{2}{*}{$\begin{array}{c}\text { Mean } \\
\text { Ranking }\end{array}$} \\
\hline & $\begin{array}{l}\text { Covenant } \\
\text { University } \\
\text { (A) }\end{array}$ & $\begin{array}{c}\text { Bells } \\
\text { University } \\
\text { (B) }\end{array}$ & $\begin{array}{c}\text { Crawford } \\
\text { University } \\
\text { (C) }\end{array}$ & \\
\hline Electricity supply & $1^{\mathrm{st}}$ & $1^{\text {st }}$ & $7^{\text {th }}$ & $1^{\text {st }}$ \\
\hline Ceiling finishing & $4^{\text {th }}$ & $3^{\text {rd }}$ & $5^{\text {th }}$ & $2^{\text {nd }}$ \\
\hline Windows/doors & $1^{\text {st }}$ & $13^{\text {th }}$ & $1^{\text {st }}$ & $3^{\text {rd }}$ \\
\hline Furniture (e.g tables, chairs e.t.c) & $4^{\text {th }}$ & $2^{\text {nd }}$ & $13^{\text {th }}$ & $4^{\text {th }}$ \\
\hline Classrooms aesthetics & $4^{\text {th }}$ & $12^{\text {th }}$ & $2^{\text {nd }}$ & $4^{\text {th }}$ \\
\hline Wall finishing & $4^{\text {th }}$ & $5^{\text {th }}$ & $11^{\text {th }}$ & $6^{\text {th }}$ \\
\hline Constant water supply in the toilets & $4^{\text {th }}$ & $15^{\text {th }}$ & $3^{\mathrm{rd}}$ & $6^{\text {th }}$ \\
\hline $\begin{array}{l}\text { Visual comfort (Natural and } \\
\text { Artificial lighting) }\end{array}$ & $1^{\text {st }}$ & $8^{\text {th }}$ & $16^{\text {th }}$ & $8^{\text {th }}$ \\
\hline Sewage system & $16^{\text {th }}$ & $5^{\text {th }}$ & $3^{\text {rd }}$ & $8^{\text {th }}$ \\
\hline Floor finishing & $18^{\text {th }}$ & $4^{\text {th }}$ & $6^{\text {th }}$ & $10^{\text {th }}$ \\
\hline Classrooms size & $10^{\text {th }}$ & $13^{\text {th }}$ & $7^{\text {th }}$ & $11^{\text {th }}$ \\
\hline Air quality within the classrooms & $12^{\text {th }}$ & $10^{\text {th }}$ & $9^{\text {th }}$ & $11^{\text {th }}$ \\
\hline No of toilets & $4^{\text {th }}$ & $15^{\text {th }}$ & $12^{\text {th }}$ & $11^{\text {th }}$ \\
\hline $\begin{array}{l}\text { Thermal comfort } \quad \text { (indoor } \\
\text { temperature) }\end{array}$ & $13^{\text {th }}$ & $9^{\text {th }}$ & $10^{\text {th }}$ & $14^{\text {th }}$ \\
\hline Escape routes & $15^{\text {th }}$ & $7^{\text {th }}$ & $15^{\text {th }}$ & $15^{\text {th }}$ \\
\hline Acoustic comfort (sound proof) & $14^{\text {th }}$ & $10^{\text {th }}$ & $18^{\text {th }}$ & $16^{\text {th }}$ \\
\hline Fan & $11^{\text {th }}$ & $17^{\text {th }}$ & $17^{\text {th }}$ & $17^{\text {th }}$ \\
\hline $\begin{array}{l}\text { Separate toilet facilities for male and } \\
\text { female students }\end{array}$ & $19^{\text {th }}$ & $17^{\text {th }}$ & $14^{\text {th }}$ & $18^{\text {th }}$ \\
\hline Internet facilities & $19^{\text {th }}$ & $20^{\text {th }}$ & $19^{\text {th }}$ & $19^{\text {th }}$ \\
\hline $\mathrm{A} / \mathrm{C}$ & $20^{\text {th }}$ & $17^{\text {th }}$ & $20^{\text {th }}$ & $19^{\text {th }}$ \\
\hline
\end{tabular}

When the results were analysed per University according to the students' grading, it shows varying levels of satisfaction with electricity supply, ceiling finishes, windows/doors and furniture in their classrooms (see Appendix 1, 2 and 3). According to the grading made by the students of each University, University A has the highest mean value for electricity (4.34), ceiling finishes (4.33), windows/doors (4.34) and furniture (4.33) while University B has the least [electricity supply(3.86); ceiling finishes(3.83); windows/doors (3.69) and furniture (3.84)]. 


\section{Concluding Remarks and Recommendations}

Conducting student satisfaction surveys is very significant in private universities in Nigeria in order to withstand the competition in the private education sector and also improve students' academic performance; since a close relationship exists between the physical environment and the academic performance of students. Classrooms are one facility where satisfaction surveys are necessary because students (of any discipline) spend a considerable amount of time using this facility (Wakefield and Blodgett, 1994; Leung, Lu and Ip, 2005). Hence, this study has attempted to investigate students' satisfaction with classroom facilities in three private Universities in Nigeria. In line with the findings, it is recommended that the Managements of the Universities should work continuously towards ensuring that this facility is given priority in financial decisions and provisions. It is also recommended that these institutions should be responsive to the expectations and needs of the students in order to improve their satisfaction which will in turn increase their academic performance and the Universities' patronage.

\section{References}

Abbasi, M. N., Malik, A., Chaudhry, I. S., \& Imdadullah, M. (2011). A Study on Student Satisfaction in Pakistani Universities: The Case of Bahauddin Zakariya University, Pakistan. Asian Social Science, 7(7), 209-219. http://dx.doi.org/10.5539/ass.v7n7p209

Adeniran, P. (2011). User Satisfaction with Academic Libraries Services: Academic Staff and Students Perspectives, International Journal of Library and Information Science, 3, 209-216. http://dx.doi.org/10.5897/IJLIS11.045

Adewunmi, Y., Omirin, M., \& Famuyiwa, F. (2011). Post-occupancy Evaluation of Postgraduate Hostel Facilities. Facilities, 29(3/4), 149-168. http://dx.doi.org/10.1108/02632771111109270

Aga, M., \& Safakli, O. V. (2007). An Empirical Investigation of Service Quality and Customer Satisfaction in Professional Accounting Firms: Evidence from North Cyprus, Problem and Perspective in Management, 5(1), 84-98.

Amole, D. (2009). Residential Satisfaction in Students' Housing, Journal of Environmental Psychology, 29, 76-85. http://dx.doi.org/10.1177/0013916508322175

Arambewela, R., \& Hall, J (2007). A Model of Student Satisfaction: International Postgraduate Students from Asia, European Advances in Consumer Research, 8, 129-135.

Asiabaka, I. P. (2008). The Need for Effective Facility Management in Schools in Nigeria. New York Science Journal, 1(2), 10-21.

Asika, N. (2004). Research Methodology: A Process Approach $1^{\text {st }}$ Ed. Lagos: Longman Nigeria Plc. 
Fong-Ling, F. (2010). Comparison of Students' Satisfaction and Dissatisfaction Factors in Different Classroom Types in Higher Education, Hybrid Learning, 6284, 415-426. http://dx.doi.org/10.1007\%2F978-3-642-14657-2_38

Iwhiwhu, B. E., \& Okorodudu, P. O. (2012). Public Library Information Resources, Facilities and Services: Users Satisfaction with Edo State Central Library, Benin City, Nigeria. Library Philosophy and Practice (e-journal), Available @ http://digitalcommons.unl.edu/libphilprac/747

Kannappanavar, B. U., \& Swamy, H. M. C. (2012). User Education in Agricultural Science University Libraries in India with Special reference to South India. Library Philosophy and Practice (e-journal). Available @ http://digitalcommons.unl.edu/libphilprac/720

Kassim, N. A. (2009). Evaluating Users' Satisfaction on Academic Library Performance.

Malaysian Journal of Library \& Information Science, 14(2), 101-115

Khan, M. M., Ahmed, I., \& Nawaz, M. M. (2011). Student's Perspective of Service Quality in Higher Learning Institutions: An Evidence Based Approach. International Journal of Business and Social Science, 2(11), 159-164.

Kleen, B., \& Shell, L. W. (2001) SERVQUAL-Based Measurement of Student Satisfaction with Classroom Instructional Technologies: A 2001 Update. Proceedings of the International Academy for Information Management (IAIM) Annual Conference: International Conference on Informatics Education \& Research (ICIER) (16th, New Orleans, LA, December 14-16). Available@ http://files.eric.ed.gov/fulltext/ED474090.pdf

Kleen, B. Shell, L. W., \& Cox, K. C. (1999) Measuring Student Satisfaction with Instructional Technology Across Business Disciplines. Proceedings of the International Academy for Information Management, Charlotte, North Carolina, 142-152.

Kleen, B., Shell, L. W., \& Zachry, B. (2001). Measuring Student Satisfaction with Instructional Technology in Accounting Information Systems Classrooms. Proceedings of the Decision Sciences Institute, Southwest Region, New Orleans, pp. 134-136

Malik, M. E., Danish, R. Q., \& Usman, A. (2010). The Impact of Service Quality on Students' Satisfaction in Higher Education Institutes of Punjab. Journal of Management Research, 2(2), 1-11, http://dx.doi.org/10.5296/jmr.v2i2.418

Manjunatha, K., \& Shivalingaiah, D. (2004). Customer's Perception of Service Quality in Libraries. Annals of Library and Information Studies, 51(4), 145-151.

Marimuthu, M., \& Ismail, I. (2012). Service Quality in Higher Education: Comparing the Perceptions of Stakeholders, Ninth AIMS International Conference on Management, January $1-4$, India.

Nwagwu, N. A. (1978). Primary School Administration. Lagos Macmillian Nigerian Publishers.

Ogunsaju, S. (1980). Some Aspects of School Management, Ibadan, Nigeria. 


\section{Macrothink}

Journal of Studies in Education

ISSN 2162-6952

2015, Vol. 5, No. 4

Osondu, M. C., \& Solomon-Uwakwe, B. (2010). Positioning Library and Information Services for User Satisfaction through ICT Policy Formulation in Nigeria. Available @ www.irma-international.org/viewtitle/45410.

Rajesh, R., Akhil, C. V., Muhammad, N. I. P., Sachin, V. S., \& Vishnu, K. (2014). Survey on Student's Perception of Class Room Environment in an Engineering College, Journal of Education and Practice, 5(37), 80-91.

Rehman, S. U., Shafique, F., \& Mahmood, K. (2011). A Survey of User Perception and Satisfaction with Reference Services in University Libraries of Punjab. Library Philosophy and Practice. (e-journal) http://digitalcommons.unl.edu/libphilprac/624

Seneviratne, D. (2006). Measuring User Satisfaction: A Case Study at the PGlM Branch Library at Peradeniya. Journal of the University Librarians Association of Sri Lanka, 10, 40-53. http://doi.org/10.4038/jula.v10i0.317

Tella, A., Owolabi, K. A., \& Attama, R. O. (2009). Student Use of the Library: A Case Study at Akanu Ibiam Federal Polytechnic, Unwana, Nigeria, Chinese Librarianship: An International Electronic Journal, 28. URL: http://www.iclc.us/cliej/cl28TOA.htm

Usman, A. (2010). The Impact of Service Quality on Students' Satisfaction in Higher Education Institutes of Punjab. Journal of Management Research, 2(2). http://dx.doi.org/10.5296/jmr.v2i2.418

Wang, I., \& Shieh, C. (2006). The Relationship between Service Quality and Customer Satisfaction: The Example of CJCU Library. Journal of Information \& Optimization Sciences, 27, 193-209. http://dx.doi.org/10.1080/02522667

Yang, Z., Becerik-Gerber, B., \& Mino, L. (2013) A Study on Student Perceptions of Higher Education Classrooms: Impact of Classroom Attributes on Student Satisfaction and Performance, Building and Environment, 70, 171-188. http://dx.doi.org/10.1016/j.buildenv.2013.08.030 


\section{Appendix 1: Satisfaction with Classrooms Facilities (University A) Covenant}

\begin{tabular}{|c|c|c|c|c|c|c|c|}
\hline Facilities/Service & 5 & 4 & 3 & 2 & 1 & Mean & Ranking \\
\hline Electricity supply & $55(34)$ & $107(66)$ & $0(0)$ & $0(0)$ & $0(0)$ & 4.34 & $1^{\text {st }}$ \\
\hline $\begin{array}{l}\text { Visual comfort } \\
\text { (Natural and Artificial } \\
\text { lighting) }\end{array}$ & $55(34)$ & $107(66)$ & $0(0)$ & $0(0)$ & $0(0)$ & 4.34 & $1^{\text {st }}$ \\
\hline Windows/doors & $55(34)$ & $107(66)$ & $0(0)$ & $0(0)$ & $0(0)$ & 4.34 & $1^{\text {st }}$ \\
\hline $\begin{array}{l}\text { Furniture (e.g tables, } \\
\text { chairs e.t.c) }\end{array}$ & $54(33)$ & $108(67)$ & $0(0)$ & $0(0)$ & $0(0)$ & 4.33 & $4^{\text {th }}$ \\
\hline Ceiling finishing & $53(33)$ & $109(67)$ & $0(0)$ & $0(0)$ & $0(0)$ & 4.33 & $4^{\text {th }}$ \\
\hline Wall finishing & $53(33)$ & $109(67)$ & $0(0)$ & $0(0)$ & $0(0)$ & 4.33 & $4^{\text {th }}$ \\
\hline Classrooms aesthetics & $54(33)$ & $108(67)$ & $0(0)$ & $0(0)$ & $0(0)$ & 4.33 & $4^{\text {th }}$ \\
\hline No of toilets & $54(33)$ & $108(67)$ & $0(0)$ & $0(0)$ & $0(0)$ & 4.33 & $4^{\text {th }}$ \\
\hline $\begin{array}{l}\text { Constant water supply } \\
\text { in the toilets }\end{array}$ & $54(33)$ & $108(67)$ & $0(0)$ & $0(0)$ & $0(0)$ & 4.33 & $4^{\text {th }}$ \\
\hline Classrooms size & $51(31)$ & 111(69) & $0(0)$ & $0(0)$ & $0(0)$ & 4.31 & $10^{\text {th }}$ \\
\hline Fan & $49(30)$ & $113(70)$ & $0(0)$ & $0(0)$ & $0(0)$ & 4.30 & $11^{\text {th }}$ \\
\hline $\begin{array}{l}\text { Air quality within the } \\
\text { classrooms }\end{array}$ & $56(34)$ & $6(4)$ & $100(62)$ & $0(0)$ & $0(0)$ & 3.73 & $12^{\text {th }}$ \\
\hline $\begin{array}{l}\text { Thermal comfort } \\
\text { (indoor temperature) }\end{array}$ & $51(31)$ & $11(7)$ & $100(62)$ & $0(0)$ & $0(0)$ & 3.70 & $13^{\text {th }}$ \\
\hline $\begin{array}{ll}\begin{array}{l}\text { Acoustic } \\
\text { (sound proof) }\end{array} & \text { comfort } \\
\end{array}$ & $50(31)$ & $12(7)$ & $100(62)$ & $0(0)$ & $0(0)$ & 3.69 & $14^{\text {th }}$ \\
\hline Escape routes & $47(29)$ & $15(9)$ & $100(62)$ & $0(0)$ & $0(0)$ & 3.67 & $15^{\text {th }}$ \\
\hline Sewage system & $54(33)$ & $8(5)$ & $0(0)$ & $100(62)$ & $0(0)$ & 3.10 & $16^{\text {th }}$ \\
\hline Internet facilities & $54(33)$ & $8(5)$ & $0(0)$ & $100(62)$ & $0(0)$ & 3.10 & $16^{\text {th }}$ \\
\hline Floor finishing & $53(33)$ & $9(5)$ & $0(0)$ & $100(62)$ & $0(0)$ & 3.09 & $18^{\text {th }}$ \\
\hline $\begin{array}{l}\text { Separate toilet facilities } \\
\text { for male and female } \\
\text { students }\end{array}$ & $51(31)$ & $11(7)$ & $0(0)$ & $100(62)$ & $0(0)$ & 3.08 & $19^{\text {th }}$ \\
\hline $\mathrm{A} / \mathrm{C}$ & $0(0)$ & $0(0)$ & $0(0)$ & $0(0)$ & $\begin{array}{c}162 \\
(100)\end{array}$ & 1.00 & $20^{\text {th }}$ \\
\hline
\end{tabular}

(Note: The Figures in brackets are percentages of responses) 
Appendix 2: Satisfaction with Classrooms Facilities (University B) Bells

\begin{tabular}{|c|c|c|c|c|c|c|c|c|}
\hline \multicolumn{2}{|c|}{ Facilities/Service } & 5 & 4 & 3 & 2 & 1 & Mean & Ranking \\
\hline \multicolumn{2}{|c|}{ Electricity supply } & $38(33)$ & $39(34)$ & $29(25)$ & $5(4)$ & $5(4)$ & 3.86 & $1^{\text {st }}$ \\
\hline \multicolumn{2}{|c|}{$\begin{array}{l}\text { Furniture (e.g tables, } \\
\text { chairs e.t.c) }\end{array}$} & $37(32)$ & $37(32)$ & $35(30)$ & $1(1)$ & $6(5)$ & 3.84 & $2^{\text {nd }}$ \\
\hline \multicolumn{2}{|c|}{ Ceiling finishing } & $33(28)$ & $38(33)$ & $40(34)$ & $2(2)$ & $3(3)$ & 3.83 & $3^{\text {rd }}$ \\
\hline \multicolumn{2}{|c|}{ Floor finishing } & $30(26)$ & $42(36)$ & $38(33)$ & $4(3)$ & $2(2)$ & 3.81 & $4^{\text {th }}$ \\
\hline \multicolumn{2}{|c|}{ Wall finishing } & $40(34)$ & $34(29)$ & $25(21)$ & $13(11)$ & $4(3)$ & 3.80 & $5^{\text {th }}$ \\
\hline \multicolumn{2}{|c|}{ Sewage system } & $33(28)$ & $39(34)$ & $32(28)$ & $12(10)$ & $0(0)$ & 3.80 & $5^{\text {th }}$ \\
\hline \multicolumn{2}{|c|}{ Escape routes } & $29(25)$ & $43(37)$ & $39(34)$ & $1(1)$ & $4(3)$ & 3.79 & $7^{\text {th }}$ \\
\hline \multicolumn{2}{|c|}{$\begin{array}{l}\text { Visual comfort (Natural } \\
\text { and Artificial lighting) }\end{array}$} & $35(30)$ & $39(34)$ & $29(25)$ & $8(7)$ & $5(4)$ & 3.78 & $8^{\text {th }}$ \\
\hline \multicolumn{2}{|c|}{$\begin{array}{l}\text { Thermal comfort (indoor } \\
\text { temperature) }\end{array}$} & $33(28)$ & $37(32)$ & $35(30)$ & $7(6)$ & $4(4)$ & 3.76 & $9^{\text {th }}$ \\
\hline \multicolumn{2}{|c|}{$\begin{array}{l}\text { Acoustic comfort (sound } \\
\text { proof) }\end{array}$} & $25(22)$ & $42(36)$ & $45(39)$ & $0(0)$ & $4(3)$ & 3.72 & $10^{\text {th }}$ \\
\hline \multicolumn{2}{|c|}{$\begin{array}{l}\text { Air quality within the } \\
\text { classrooms }\end{array}$} & $31(27)$ & $39(33)$ & $31(27)$ & $12(10)$ & $3(3)$ & 3.72 & $10^{\text {th }}$ \\
\hline \multicolumn{2}{|c|}{ Classrooms aesthetics } & $26(22)$ & $36(31)$ & $51(44)$ & $0(0)$ & $3(3)$ & 3.71 & $12^{\text {th }}$ \\
\hline \multicolumn{2}{|c|}{ Classrooms size } & $31(27)$ & $38(33)$ & $33(28)$ & $8(7)$ & $6(5)$ & 3.69 & $13^{\text {th }}$ \\
\hline \multicolumn{2}{|c|}{ Windows/doors } & $24(21)$ & $38(33)$ & $49(42)$ & $4(3)$ & $1(1)$ & 3.69 & $13^{\text {th }}$ \\
\hline \multicolumn{2}{|c|}{ No of toilets } & $32(27)$ & $39(34)$ & $22(19)$ & $22(19)$ & $1(1)$ & 3.68 & $15^{\text {th }}$ \\
\hline \multicolumn{2}{|c|}{$\begin{array}{l}\text { Constant water supply in } \\
\text { the toilets }\end{array}$} & $32(27)$ & $35(30)$ & $34(29)$ & $10(10)$ & $5(4)$ & 3.68 & $15^{\text {th }}$ \\
\hline \multicolumn{2}{|c|}{$\begin{array}{l}\text { Separate toilet facilities } \\
\text { for male and female } \\
\text { students }\end{array}$} & $22(19)$ & $42(36)$ & $43(37)$ & $8(7)$ & $1(1)$ & 3.66 & $17^{\text {th }}$ \\
\hline \multirow{2}{*}{$\begin{array}{l}\text { Cooling } \\
\text { system }\end{array}$} & Fan & $29(25)$ & $42(36)$ & $23(20)$ & $20(17)$ & $2(2)$ & 3.66 & $17^{\text {th }}$ \\
\hline & $\mathrm{A} / \mathrm{C}$ & $32(28)$ & $34(29)$ & $30(26)$ & $18(15)$ & $2(2)$ & 3.66 & $17^{\text {th }}$ \\
\hline \multicolumn{2}{|c|}{ Internet facilities } & $23(20)$ & $41(35)$ & $37(32)$ & $15(13)$ & $0(0)$ & 3.62 & $20^{\text {th }}$ \\
\hline
\end{tabular}

(Note: The Figures in brackets are percentages of responses) 
Appendix 3: Satisfaction with Classrooms Facilities (University C) Crawford

\begin{tabular}{|c|c|c|c|c|c|c|c|}
\hline Facilities/Service & 5 & 4 & 3 & 2 & 1 & Mean & Ranking \\
\hline Windows/doors & $72(47)$ & $62(40)$ & $16(10)$ & $4(3)$ & $0(0)$ & 4.31 & $1^{\text {st }}$ \\
\hline Classrooms aesthetics & $74(48)$ & $56(36)$ & $20(13)$ & $4(3)$ & $0(0)$ & 4.30 & $2^{\text {nd }}$ \\
\hline Sewage system & $80(52)$ & $47(31)$ & $16(10)$ & $11(7)$ & $0(0)$ & 4.27 & $3^{\text {rd }}$ \\
\hline $\begin{array}{l}\text { Constant water supply in } \\
\text { the toilets }\end{array}$ & $73(47)$ & $54(35)$ & $23(15)$ & $4(3)$ & $0(0)$ & 4.27 & $3^{\text {rd }}$ \\
\hline Ceiling finishing & $75(49)$ & $53(34)$ & $15(10)$ & $11(7)$ & $0(0)$ & 4.25 & $5^{\text {th }}$ \\
\hline Floor finishing & $74(48)$ & $54(35)$ & $15(10)$ & $11(7)$ & $0(0)$ & 4.24 & $6^{\text {th }}$ \\
\hline Electricity supply & $68(44)$ & $62(40)$ & $13(8)$ & $11(7)$ & $0(0)$ & 4.21 & $7^{\text {th }}$ \\
\hline Classrooms size & $66(43)$ & $58(38)$ & $26(17)$ & $4(3)$ & $0(0)$ & 4.21 & $7^{\text {th }}$ \\
\hline $\begin{array}{l}\text { Air quality within the } \\
\text { classrooms }\end{array}$ & $65(42)$ & $67(44)$ & $8(5)$ & $14(9)$ & $0(0)$ & 4.19 & $9^{\text {th }}$ \\
\hline $\begin{array}{l}\text { Thermal comfort (indoor } \\
\text { temperature) }\end{array}$ & $74(48)$ & $50(32)$ & $19(12)$ & $4(3)$ & $7(5)$ & 4.17 & $10^{\text {th }}$ \\
\hline Wall finishing & $69(45)$ & $55(35)$ & $15(10)$ & $15(10)$ & $0(0)$ & 4.16 & $11^{\text {th }}$ \\
\hline No of toilets & $60(39)$ & $67(44)$ & $16(10)$ & $11(7)$ & $0(0)$ & 4.14 & $12^{\text {th }}$ \\
\hline $\begin{array}{l}\text { Furniture (e.g tables, } \\
\text { chairs e.t.c) }\end{array}$ & $61(39)$ & $56(36)$ & $30(20)$ & $7(5)$ & $0(0)$ & 4.11 & $13^{\text {th }}$ \\
\hline $\begin{array}{l}\text { Separate toilet facilities } \\
\text { for male and female } \\
\text { students }\end{array}$ & $72(46)$ & $30(20)$ & $38(25)$ & $14(9)$ & $(0)$ & 4.04 & $14^{\text {th }}$ \\
\hline Escape routes & $52(33)$ & $72(47)$ & $19(12)$ & $4(3)$ & $7(5)$ & 4.03 & $15^{\text {th }}$ \\
\hline $\begin{array}{l}\text { Visual comfort (Natural } \\
\text { and Artificial lighting) }\end{array}$ & $66(43)$ & $44(29)$ & $23(15)$ & $21(13)$ & $0(0)$ & 4.01 & $16^{\text {th }}$ \\
\hline Fan & $51(33)$ & $73(47)$ & $15(10)$ & $8(5)$ & $7(5)$ & 3.99 & $17^{\text {th }}$ \\
\hline $\begin{array}{l}\text { Acoustic comfort (sound } \\
\text { proof) }\end{array}$ & $60(39)$ & $43(28)$ & $37(24)$ & $14(9)$ & $0(0)$ & 3.97 & $18^{\text {th }}$ \\
\hline Internet facilities & $44(28)$ & $74(48)$ & $22(14)$ & $7(5)$ & $7(5)$ & 3.92 & $19^{\text {th }}$ \\
\hline $\mathrm{A} / \mathrm{C}$ & $50(33)$ & $53(35)$ & $30(19)$ & $21(13)$ & $0(0)$ & 3.86 & $20^{\text {th }}$ \\
\hline
\end{tabular}

(Note: The Figures in brackets are percentages of responses) 